\title{
DEVELOPMENT EFFECT OF TEACHER PROFESSIONAL ABILITIES THROUGH TRAINING ON THE PROFESSIONAL COMPETENCY OF TEACHERS AND TEACHER PERFORMANCE OF STATE JUNIOR HIGH SCHOOLS IN THE CITY OF BANDUNG
}

\author{
Dadang Rahman Munandar \\ FKIP, University of Singaperbangsa Karawang (Unsika) \\ drdadangrahman@gmail.com \\ N. Fathurrohman \\ MPI - FAI University of Singaperbangsa Karawang (Unsika) \\ n.fathurrohman@fai.unsika.ac.id
}

\begin{abstract}
The development of teacher professional abilities through training is an effort to improve teacher performance by increasing their professional competence. The main objective of developing teacher professional abilities through training is to solve teacher performance weaknesses both at present and in the future towards a more desirable level of performance. Because the development of teacher professional abilities through training is so important and requires a lot of money, it is necessary to research to find a real effect on teacher competence and performance. The research problems formulated are: 1) dimensions of teacher professional ability development through training; 2) teacher professional competence; and 3) teacher performance. The research approach is quantitative with a sample of 335 from a population of 2,064 junior high school teachers in Bandung. Data were obtained from teachers using a questionnaire. The data is processed and interpreted using path analysis as an inferential statistical technique by first testing statistical assumptions, including transforming ordinal data into intervals and data normality testing. The study concluded that the development of teacher professional abilities can improve teacher competence and performance, which is expected to ultimately improve the quality of student learning. The implications include: 1) it is necessary to develop effective training; and 2) competence with performance is important to promote better teaching and learning. Based on these implications, there are several recommendations, namely: 1) increasing the development of teacher professional abilities through technical assistance and quality control group forums; (2) designing the development of teacher professional abilities that have a direct impact on the teaching and learning process; (3) develop a model with competency as the dependent variable; and (4) recommend the human side of the organization as a determinant factor that needs to be investigated.
\end{abstract}

\section{A. INTRODUCTION}

Modern society has started to place education as a strategic component (Basic Development) to improve the quality of human resources, for this reason education must be organized in a system so that the investment is clear, effective and controlled (Tresch, 1981 : 44-60). Efforts to improve the quality of education are one of the priorities of education in Indonesia, especially at the primary and secondary education levels. If we examine carefully the many projects to improve the quality of education that have been 
carried out since 1990 (Kanwil Depdiknas, 2000), especially in West Java Province, it revolves around the problem of curriculum development, packaging of learning materials, teacher education and training and other matters that are directly related to the teaching and learning process.

The development of education personnel, especially improving the quality of teachers, is the key to improving the quality of education because the presence of teachers in the National Education System is seen as the main element of education personnel. In Government Regulation number 38 of 1992 concerning education personnel it is stated that :

"Education personnel are the most important element in the national education system which is held and developed to provide teaching and training for students. Among the educational staff, the teaching staff (Teacher) is the main element' (Tenaga Kependidikan, 1992).

The teacher occupies a central and strategic function in the learning process because technically it can translate the improvement process in the education system into one activity in the classroom. In the context of the learning process in the classroom, the teacher positions himself as a facilitator as well as a motivator so that students are able to develop their potential to absorb, explore, and find scientific concepts and values that are taught in class independently. Therefore teachers must have adequate teacher quality.

According to Muhibbin Syah, teachers who have adequate teacher quality are competent teachers or those who have the ability to carry out their obligations responsibly and properly. (Syah, 1999 : 229). According to Jhonson in Abin Syamsudin there are at least five components that support teacher competence, namely: 1) the teaching material component (The theaching subject component), 2) the professional ability component (The professional component), 3) the learning process component (The process component). , 4) the adjustment component, 5) the attitude component, all of these components are actualized in the quality of work / work performance or performance (performance component) which is reflected in the quality of learning. (Makmun, $1998: 71$ ).

Based on a preliminary study of data obtained from the education and training activity report document carried out within the Regional Office of the Ministry of National Education (now the Education Office) of West Java Province through the SLTP project, expansion and quality improvement and the Basic Education Project for 1999- 2000, there were various upgrading activities (education and training) for junior high school teachers in West Java in an effort to improve and develop the quality of learning.

Upgrading activities (education and training) that have been carried out include upgrading of subject teachers and development / preparation of question construction carried out through the cluster system (BEP) and empowerment of MGMP (SLTP project expansion and quality improvement), there are +9750 junior high school teachers in Java West received training for 7 to 10 working days (90 lesson hours), especially for state junior high school teachers in Bandung City at least 247 teachers have improved their abilities (Depdiknas, 2000). 
The problem that becomes the study is whether there is a significant contribution to the condition of junior high school teachers in the city of Bandung to the effective and efficient learning process, whereas the ineffective and cumulative learning process is very influential on the quality of education In this regard, it is necessary to seek a comprehensive solution for teacher training, so that it becomes an input to determine policies in planning to improve the professional quality of teachers, which in turn can improve teacher performance and teaching and learning activities. This condition is interesting to be used as research "The effect of teacher development on teacher competence and performance" is the formulation of the topic of study in the research that will be carried out.

\section{B. RESEARCH METHOD}

Research on junior high school teachers in Bandung on the effect of teacher development through the education and training system on teacher competence and performance in carrying out professional duties is carried out through quantitative research. There are two independent variables $\mathrm{X} 1$ (teacher development through the training / upgrading system) $\mathrm{X} 2$ (competence) and one devendent variable $Y$ (teacher performance in carrying out professional duties) which are the studies in the research to be carried out.

Based on data processed by the Information and Data Section of the West Java Provincial Education Office in Bandung City, there are 51 State Junior High Schools and 2064 public teachers spread across diploma qualifications and various teaching assignments.

In the research carried out, basically the data were obtained from two sources consisting of (1) personal data sources which included school supervisors, school principals, administrative staff, relevant teachers and students and (2) written data sources, namely the results data. distributing questionnaires to school supervisors, school principals, administrative staff, teachers concerned, students and documentation data in the form of personnel data and student learning achievement data in schools where the teachers used as research samples carry out teaching tasks.

\section{RESULTS AND DISCUSSIONS}

\section{Overview of Teacher Development, Teacher Competence and Teacher Performance}

The teacher development variables above have dimensions, namely the type of training that has been attended, the essence of the training material, the level of training that has been attended and the impact of the education and training on teaching and learning activities. These dimensions reveal the trend of the data through each indicator which is carried out in an integrated manner through questions of the teacher development variable instrument. The data obtained shows a tendency to focus on the average group that is close to the perfect normal curve. Based on the results of the calculation, the average X1 
variable is 61.14 or $61.1 \%$ of the ideal score. This price is in the high enough category according to the predefined classifications and it can be concluded that teacher development is manifested in a fairly high category.

Teacher competency variables have dimensions, namely professional abilities consisting of mastery of materials, the ability to plan, implement and assess learning. These dimensions reveal the trend of the data through the respective indicators which are carried out in an integrated manner through questions of the teacher competency variable instrument. The data obtained turns out to show a tendency to focus on the average group that is close to the perfectly normal curve. The description of this variable fulfills the statistical test requirements in order to test the hypothesis. Based on the calculation results, the average X2 variable is 55.4 or $55.4 \%$ of the ideal score. This price is in the high enough category according to the predetermined classification and it can be concluded that the competence of teachers is categorized as high enough.

The teacher performance variable reveals the tendency of the data through the dimensions of the experience, skill, knowledge, initiative, adaptability, personal integrity and judgment ability in the learning process. The data obtained turns out to show a tendency to focus on the average group that is close to the perfectly normal curve. The description of this variable fulfills the statistical test requirements in order to test the hypothesis. Based on the calculation results, the $Y$ variable average is 74.1 or $74.1 \%$ of the ideal score. This price is in the high enough category according to the predetermined classification and it can be concluded that the teacher's performance is in the high enough category.

This general trend indicates that teacher development through training has reached a sufficient level which results in adequate teacher competence and performance. This indicates that the trainings that have been carried out are quite good teacher development activities.

Initial research data on teacher development, namely upgrading activities (education and training) that have been carried out include upgrading of subject teachers and development I preparation of question construction carried out through the cluster system (BEP) and empowerment of MGMP (SLTP project expansion and quality improvement), there are + 9750 junior high school teachers in West Java received training for 7 sd 10 working days (90 lesson hours), especially for State Junior High School teachers in Bandung City at least 247 teachers have improved their abilities (Depdiknas, 2000). These data indicate that teacher development is a good enough initial step to improve teacher competence and teacher performance.

Teacher is a position or profession that requires special skills as a teacher. This job cannot be done by people who do not have the skills to do activities or work as a teacher. As for the other meaning of teachers are professional educators with the main task of educating, teaching, guiding directing, training, assessing, and evaluating students in formal education, basic education, and secondary education (Syaifuddin \& Usman, 2002 : 15). 


\section{The Effect of Teacher Development on Teacher Competenceu}

The effect of teacher development through training on teacher competence proved to be significant at the $95 \%$ confidence level with a correlation index of 0.893 or the direct effect of teacher development through training on competence was $79.74 \%$. While other variables that affect the competency index 0.47889 or $22.93 \%$. This data shows that teacher development through training is still an effort that needs to be maintained in increasing competence because human resources are the most important resource that an organization must have without except educational organizations (educational institutions) one of the implications is the most important investment that an organization may make. is in the field of human resources through development and training (Siagian, 1999: 181).

The difference between the teaching profession and other professions lies in their duties and responsibilities. These duties and responsibilities are closely related to the skills required to take up the profession. Usman stated that, "Teacher is a position or profession that requires special expertise as a teacher". Therefore, every teacher at an educational institution must have various provisions or requirements to become a teacher. One of these requirements is having the competence (ability) to carry out teaching and educational activities optimally. Another requirement is that teachers must be mentally and physically healthy, and have a teacher certificate issued by a teacher education institution (Usman, 2007 : 1).

Another reason for the importance of teacher development is that changes or innovations in the field of education are increasingly being intensified, continuously being introduced by the government. Change will not be meaningful without the ability of human resources to adapt to these changes. One concept that is considered good enough to improve the ability of human resources to adapt to these changes is the development of the concept of learning community by schools or the concept of learning organization, both in small environments at schools and in groups of teachers of similar subjects or MGMP at school level, clusters and at the district / city and provincial levels

Other variables that affect teacher competence that must be taken into account are job content and context (Pareek, 1983). The job context relates to salary, supervision and other factors outside of job content. Meanwhile, content is related to the nature and types of work that provide opportunities for teachers to develop their competences.

Competence is a set of knowledge, skills and behaviors that must be internalized and mastered by teachers in order to carry out their professional duties. (Sagala, $2009: 23$ ).

\section{Effect of Competence on Teacher Performance}

The effect of teacher competence on teacher performance was proven significant at the $95 \%$ confidence level with a correlation index of 0.381 or the direct effect of teacher competence on performance was $14.52 \%$. Meanwhile, other variables that affect the index performance are 0.9245 or $85.47 \%$. Other factors that affect teacher performance are so great that the factors that need to be considered according to Castetter suggest that in 
general there are three main sources of ineffective employee performance, as follows: (1) individual factors, (2) organizational factors and (3) fator environment. Performance is the actualization of competencies that can be reflected in work processes, work results and individual characteristics. In this study, performance is focused on individual characteristics. Although performance research is traced from one side, the results of the study provide important clues that other factors, especially organization and the environment, need to be used as benchmarks in optimizing performance in addition to teacher competence. (Casteter, $1981: 281$ ).

Performance and competence are variables functionally interacting with each other. Competence reflects performance, and vice versa. However, that does not mean that competence is identical to performance. Competence refers more to the real and potential abilities the teacher has as a basis (basic ability) to develop performance. Meanwhile, in addition to the actualization of competence performance, it also involves motivational factors. Individuals who are capable (competent) do not necessarily want (motivation) to work (performance). Therefore, performance is a function of ability plus motivation (will). In this study, competence is seen as a mediating variable between teacher development (training) and performance. Or in other words, performance is affected by teacher development (training) through teacher competence.

The term teacher competence has many meanings, according to Broke and Stone (1995) in suggesting that teacher competence as a descriptive of qualitative nature of theacer behavior is appealing to be entirely meaningful. Teacher competence is a qualitative description of the nature of meaningful teacher behavior (Mulyasa, $2003: 23$ ).

Sedarmayanti suggests a variety of terms of performance. According to him, performance can be translated into performance, work performance, work implementation, work achievement, work results, work performance, or work performance. The diversity of terms is reflected in the definitions of performance put forward by the following experts (Sedarmayanti, $2001: 50$ ).

Samsudin called performance as the implementation of work by defining performance as "the level of execution of tasks that can be achieved by a person, unit or division by using existing capabilities and limits that have been set to achieve organizational / company goals"(Sadilin, 2005 : 159).

Prawirosentono calls performance as the result of work by defining performance as "the work that can be achieved by a person or group of people in an organization, in accordance with their respective authorities and responsibilities. (Prawirosentono, 1999 : 2). Rivai argues that performance is the result or level of success of a person as a whole during a certain period in carrying out a task compared to various possibilities, such as work standards, targets or targets or criteria that have been determined in advance and have been mutually agreed. (Rivai, $2004: 14$ ).

Hasibuan, which refers to performance as work achievement, states that "work performance is a result of work achieved by a person in carrying out the tasks assigned to 
him based on skills, experience and sincerity and time"(Hasibuan, 2001 : 94). Mangkunegara argued that "work performance is the result of work in quality and quantity achieved by an employee in carrying out his duties in accordance with the responsibilities assigned to him" (Mangkunegara, 2000 : 67).

Based on the description above, it can be concluded that performance is the performance of a person in carrying out a task as a concrete realization of competence based on skills, experience and sincerity.

Many factors influence individual performance. Gibson classifies the variables that can affect performance, namely (1) individual variables, (2) psychological variables, and (3) organizational variables. (Gibson et al., $1996: 53$ ).

\section{Effect of Teacher Development through Training and Competence on Teacher Performance}

The results showed the findings that the indirect effect of teacher development (training) on performance through competence was $14.73 \%$. While the direct effect of teacher development (training) together with competency on teacher performance is $=0.244077$ or $5.97 \%$. The influence of other variables on teacher performance is 0.8694 or $75.58 \%$. This shows that the research paradigm is the right mindset by finding that the indirect effect of teacher development (training) on performance through competence is $14.73 \%$, while the direct effect of competence on teacher performance is $14.42 \%$. The number of direct and indirect effects is $29.15 \%$. This means that the competency variable is a mediating variable between teacher development through training and teacher performance. Or in other words, teacher performance does not arise through teacher development (training) but through the mediator, namely competence. This competence is an ability that is both potential and real as implied in the opinion of Broke and Stone in Mulyasa, namely teacher competency is the ability of a teacher to carry out obligations responsibly and properly. (Mulyasa, 2009 : 25).

The research finding that competence is a mediator between teacher development (training) and performance is the result of path analysis. What is meant by path is that the dependent variable (performance) is not directly influenced by teacher development but through a mediator, namely competence in addition to other factors (epsilon). Therefore, theoretically, it can be argued that teacher development (training) is one of the instruments of various instruments in improving performance, but more importantly the instrument must have a direct effect on competence, not performance.

\section{CONCLUSSION}

Based on the results of the research and discussion in the previous chapter, several conclusions can be drawn as follows:

1. Teacher development has dimensions, namely the type of training that has been attended, the essence of the training material, the level of training that has been 
attended and the impact of education and training on teaching and learning activities. The integration of these dimensions in percentage amounted to 61.14 or $61.1 \%$ of the ideal score, including the high enough category. Teacher competency variables have dimensions, namely professional abilities consisting of mastery of materials, the ability to plan, implement and assess learning. These dimensions are generally in a percentage of 55.4 or $55.4 \%$ of the ideal score. This price is in the quite high category. Meanwhile, the teacher performance revealed the tendency of the data through the dimensions of experience, skill, knowledge, initiative, adaptability, personal integrity and the ability of judgment in the learning process by 74.1 or $74.1 \%$ of the ideal score, including in the high enough category.

2. The effect of teacher development through education on teacher competence proved to be significant at the $95 \%$ confidence level with a correlation index of 0.893 or the direct effect of teacher development through training on competence was $79.74 \%$. While other variables that affect the competency index 0.47889 or $22.93 \%$. This data shows that teacher development through training is still an effort that needs to be maintained in increasing competence.

3. The effect of teacher competence on teacher performance proved significant at the $95 \%$ confidence level with a correlation index of 0.381 or the direct effect of teacher competence on performance was $14.52 \%$. While other variables that affect the index performance are 0.9245 or $85.47 \%$.

4. The indirect effect of teacher development through training on performance through competence is $14.73 \%$. While the direct effect of teacher development through cocompetency training on teacher performance is $=0.244077$ or $5.97 \%$. The influence of other variables on teacher performance is 0.8694 or $75.58 \%$. This shows that the research paradigm is the right mindset with the discovery of an indirect effect through competence which is $14.73 \%$ while the direct effect of competence on teacher performance is $14.42 \%$. The number of direct and indirect effects is $29.15 \%$. This means that the competency variable is a mediating variable between teacher development through training and teacher performance.

\section{REFERENCES}

Casteter, W. B. (1981). The Personal Function In Education Administration. MC Millan Publishing. Depdiknas. (2000). Laporan Diklat BEP dan Proyek SLTP perluasasan dan peningkatan mutu 1999-2000. Depdiknas.

Gibson, Ivancevich, \& Donnelly. (1996). Organisasi, Perilaku, Struktur, Proses, (N. Adiarni, Trans.). Bina Rupa Aksara.

Hasibuan, M. P. (2001). Manajemen Sumber Daya Manusia. Bumi Aksara.

Kanwil Depdiknas. (2000). Laporan Kantor Wilayah Departemen Pendidikan Nasional Jawa Barat. Depdikknas Jabar.

Makmun, A. S. (1998). Pengembangan Profesi dan Kinerja Tenaga Kependidikan. Program Pascasarjana IKIP Bandung.

Mangkunegara, A. P. (2000). Manajemen Sumber Daya Manusia. Rosdakarya.

Mulyasa, E. (2003). Kurikulum Berbasis Kompetensi. PT. Remaja Rosda Karya.

Mulyasa, E. (2009). Praktik Penelitian Tindakan Kelas. Rosdakarya. 
Pareek, U. (1983). Organizational Role Stress. In: Pfeiffer's Classic Inventories, Questionniares and Surveys. Universty Associates.

Tenaga Kependidikan, Pub. L. No. No. 38 (1992).

Prawirosentono, S. (1999). Kebijakan Kinerja Karyawan. BPFE.

Rivai, V. (2004). Manajemen Sumber Daya Manusia Untuk Perusahaan. PT RajaGrafindo Persada.

Sadilin, S. (2005). Manajemen Sumber Daya Manusia. Pustaka Setia.

Sagala, S. (2009). Konsep dan Makna Pembelajaran. CV. Sahri.

Sedarmayanti. (2001). Sumber Daya Manusia dan Produktivitas Kerja. Mandar Maju.

Siagian, P. S. (1999). Manajemen Sumber Daya Manusia. Bumi Aksara.

Syah, M. (1999). Psikologi pendidikan dengan pendekatan baru. PT Remaja Rosdakarya.

Syaifuddin, \& Usman, M. B. (2002). Guru Profesional dan Implementasi Kurikulum,. Ciputat Press. Tresch, R. W. (1981). Public Finance: A Normative Theory. Business Publications, Inc.

Usman, N. (2007). Manajemen Peningkatan Kinerja Guru. Mutiara IImu. 